\author{
Malgorzata KARPIŃSKA-KRAKOWIAK ${ }^{1}$ \\ Artur MODLIŃSKI ${ }^{2}$
}

\title{
PRANKVERTISING - PRANKS AS A NEW FORM OF BRAND ADVERTISING ONLINE
}

\begin{abstract}
A practical joke (i.e. a prank) belongs to a category of disparagement humor, as it is a playful act held to amuse, tease or even mock the victim, and to entertain the audience. Although humor has been long exploited in broadcast and print advertising, the use of practical jokes is a more recent phenomenon esp. in digital marketing. The development of the Internet and social media creates new opportunities for using pranks as disguised adverts embedded in online strategies and there is an increasing number of companies which exploit pranks as a creative content solution for their on-line presence. As there is little academic endeavor devoted to this subject, this paper forwards a theoretical and practical framework for pranks. It recognizes pranks as innovative forms of digital advertising and it analyses their potential in terms of branding effectiveness (e.g. in maximizing brand reach, exposure, brand visibility, drawing consumer attention, eliciting strong emotions etc.). Possible prank effects are inferred from the theory of humor and from the secondary data collected by the authors of this paper. Key challenges, risks and limitations are discussed and relevant examples are provided. The paper concludes with several research areas and questions to be addressed in future empirical studies.
\end{abstract}

Keywords: a prank, brand, advertising online, prankvertising, brand management, advertising strategy, humor

\section{INTRODUCTION}

The Internet has become one of the most important advertising tools and it has overtaken traditional media in terms of brand-building possibilities. Year by year the online advertising market is experiencing a considerable growth and development. There is an increasing number of companies allocating their budgets in diverse forms of online communication e.g. display ads, search engine optimization, social profiles, games, and viral videos. According to Zenith Optimedia, it is online video that is one of the fastest growing advertising tools and it is expected to rise by a half to around 10 billion USD by $2016^{3}$. As videos are believed to generate traffic and online word-of-mouth, advertisers dedicate more and more resources to build appropriate video content that would contribute to positive advocacy among their target audiences. Video as a vehicle for viral marketing has

\footnotetext{
${ }^{1}$ Małgorzata Karpińska-Krakowiak, PhD, Department of International Marketing and Retailing, Faculty of International and Political Studies, University of Lodz, (corresponding author), Narutowicza 59a, 90-131 Łódź, e-mail: mkarpinska@uni.lodz.pl

${ }^{2}$ Artur Modliński, MSc, Department of Marketing, Faculty of Management, University of Lodz, Matejki 22/26, 90-237 Łódź, e-mail: modliński@uni.lodz.pl

${ }^{3}$ Media firms are making big bets on online video, still an untested medium, New York, 3 May 2014, http://www.economist.com/news/business/21601558-media-firms-are-making-big-bets-online-video-stilluntested-medium-newtube.
} 
thus become an applauded lever for emotions, engagement and positive on-brand behaviors ${ }^{4}$.

This paper addresses a very specific type of online viral videos: video pranks, i.e. advertising messages disguised as practical jokes and disseminated by brands. It analyzes their role and functions in contemporary branding campaigns on the Internet. As the concept of a branding prank has been largely understudied and under-theorized by marketing scholars, the manuscript aims at providing theoretical and practical background to this phenomenon and attempts to identify key research areas which need to be further explored. At the end of the manuscript the authors provide a list of prank videos (table 1.), which serve as exemplifications of different statements presented in the text. In order to form a complete picture of pranks in digital advertising, the readers are strongly encouraged to watch the relevant footage along with reading subsequent sections.

\section{PRANKS AND PRANKVERTISING - DEFINING A NEW CONCEPT}

A prank is a ludicrous event or act done to entertain, amuse or ridicule. As cultural anthropologist, Richard Bauman ${ }^{5}$, suggests, it is an enactment of playful deceit. A practical joke is played by a trickster on an individual (i.e. a victim) who does not expect to be a subject of any mockery or comic situation. From socio-cultural viewpoint, pranks have been recognized as a category of play, as they attempt to blur the boundaries between artifice and reality, to reverse the typical social order and hierarchy of everydayness, and, simultaneously, they are unserious, make-believe, and involve magnitude of surprise ${ }^{6}$. Typical examples range from childish joke experiments (e.g. placing salt in a sugar bowl; hanging a bucket of water above a doorway), to "adolescent" office pranks (e.g. wrapping the office desks with stretch foil, so colleagues returning from their holidays think they are fired).

From an entertainment perspective, a prank is not a new phenomenon and it has been extensively used for decades by television producers in, for example, the Candid Camera format. In contemporary marketing, however, practical jokes have just begun to be exploited for online branding purposes, which contributes to one of the latest trends, namely called prankvertising. Professional pranks (i.e. staged by advertising agencies) are usually complex performances, planned ahead of execution and with anticipated results. In digital media pranks have become a modern executional tactic for promotional messages designed to draw consumers' attention in a highly cluttered environment. They are increasingly used as a captive content for videos disseminated online by brands to promote themselves and to build a positive word-of-mouth. Such video pranks (hereafter called branding pranks) depict unsuspecting consumers caught up in a trap or set up by actors in prearranged marketing stunts. So, like in the traditional humor process, branding pranks usually involve 3 parties: an agent, an object and an audience ${ }^{7}$. Brands act as joke tellers and tricksters (agents) who set up a prank, engineer its scenario, and control the source of

\footnotetext{
${ }^{4}$ J.-K. Hsieh, Y.-C. Hsieh, Y.-C. Tang, Exploring the disseminating behaviors of eWOM marketing: persuasion in online video, "Electronic Commerce Research" 2012/12, s. 201-224.

${ }^{5}$ R. Bauman, Story, Performance, and Event: Contextual Studies in Oral Narrative, Cambridge UP, Cambridge 1986, p. 144.

${ }^{6}$ M. Karpińska-Krakowiak, Consumers, Play and Communitas - an Anthropological View on Building Consumer Involvement on a Mass Scale, "Polish Sociological Review" 3/187 (2014), p. 317-331.

${ }^{7}$ C.S. Gulas, M.G. Weinberger, Humor in Advertising: A Comprehensive Analysis, M.E. Sharpe, New York 2006.
} 
fun and humor; online users (i.e. target consumers) become the recipients of humor (an audience); and anonymous individuals are the objects (victims) of a joke.

It is the surprise and genuine reactions of objects (i.e. staged veracity of the stunt), that constitute a source of humor in branding pranks. However, the level of reality and surprise differs depending on a joke. In Carlsberg "Bikers in Cinema" prank, unsuspecting people enter the cinema where there are only limited seats available among a scarylooking group of bikers. The suspense is relieved when the most "courageous" visitors take a seat next to the bikers and are awarded with a beer for their outgoing attitude. While this situation was authentic, certain branding stunts are staged in more controlled environments, with prearranged equipment and specially selected actors. The Weather Channel (TWC), for example, officially admitted that in their prank, which had been designed to promote TWC's new Android application to forecast the weather, they used professional actors.

\section{PRANKS AND THEIR ROLE IN BRAND PROMOTION ONLINE}

One can encounter many branding pranks across diverse product categories (e.g. airlines, household appliances, toys), but most spectacular stunts are staged by companies offering their products in FMCG sectors like food, beverages and cosmetics (e.g. CocaCola, Pepsi, Heineken, Carlsberg, McDonald's, Nivea, Herbal Essences). These are predominantly low-involvement products, which have already exploited all arguments about extra attributes, functions or benefits they may provide, and they operate in highly competitive, dense markets, with extensive number of players and advertising clutter. Under such conditions, using unconventional promotional methods seems the most efficient strategy for differentiation and standing out from the online crowd.

Most frequent objectives set for branding pranks are: maximizing reach and brand visibility, generating attention, eliciting strong emotions and providing a compelling portrayal of brand core ideas. Despite their advertising origin and purpose, branding pranks do not directly promote products per se; they are not designed to sell, neither to induce immediate purchase behaviors on any viewers' part. Instead, they are introducing the viewer into the world and philosophy of a particular brand (e.g. "Push to add drama" prank held by cable network TNT); they amusingly epitomize brand values and claims (e.g. Heineken and its "Champions league match vs. classical concert" prank), attributes (e.g. Nivea "The stress test", LG "Meteor", DHL "Trojan mailing") or a reason to be (e.g. Coca-Cola "Singapore recycle happiness machine", "Happiness truck", "Happiness machine"). A product provides just a setting for playing a joke; it creates an occasion to trigger a play (e.g. a Samsung prank "All eyes on S4") and make fun of unsuspecting nonprofessionals.

Most remarkable pranks can gather a multimillion audience in a relatively short period of time. Up to date (i.e. September 2014) the mostly viewed pranks were: TNT video "Push to add drama" which had been seen 51,149,105 times in two years ${ }^{8}$, WestJet "Christmas miracle" with 36,351,790 views in nine months ${ }^{9}$, and LG "Elevator" with

\footnotetext{
${ }^{8}$ A dramatic surprise on a quiet square, http://www.youtube.com/watch?v=316AzLYfAzw (accessed: 22 September 2014).

9 WestJet Christmas Miracle: real-time giving, http://www.youtube.com/watch?v=zIEIvi2MuEk (accessed: 22 September 2014).
} 
$22,535,332$ impressions in one year ${ }^{10}$. The actual reach of these pranks may become even greater as they are frequently shared, forwarded and cited across traditional media and social networking sites. LG video "Meteor", for instance, was referred to in "Huffington Post"11, "Telegraph"12, "Daily Mail"13, "Mirror"14 etc. Similarly, positive reviews about TNT prank were presented in "Huffington Post"15, "Daily Mail"16 and even "Forbes"17.

Apart from gaining visibility online, pranks are designed to generate intense emotions. Humor in its essence has significant emotional power and appeal to massive audience. Strong emotions, as produced by humorous messages, are believed to drive onbrand behaviors, or at least leave considerable memory traces, which consumers may rely on in their subsequent decision-making. Surprisingly, it is the negative nature of emotional appeal, that seems to count for most marketing managers who attempt to advertise online with branding pranks. There are many examples of very provocative pranks, which actually base on negative emotions like fear, derision, embarrassment or mayhem. In Nivea "The stress test" prank, for instance, the objects (victims) are secretly photographed as they sit in the airport departure lounge. These images are immediately used to depict the objects as very dangerous fugitives in faux newspapers distributed around the airport and in TV programs broadcasted in that lounge. As the prankees become stressed, the airport security guards approach them with Nivea antiperspirant deodorants - the products designed to help consumers overcome the effects of stressful situations. Despite the positive closure of this video, a careful viewer would not only remember the brand, but might also associate Nivea with emotional harm and trauma experienced by the victims. Another example of a branding prank that uses non-positive humor signals was held by LG. It depicts candidates during job interviews, who are tricked into thinking that a meteor has just fallen on the city outside the office window. Albeit staged, "Meteor" video may raise viewers' sympathy and compassion as they associate themselves with humiliat-

${ }^{10}$ So Real it's Scary, http://www.youtube.com/watch?v=NeXMxuNN1E8 (accessed: 22 September 2014).

${ }^{11}$ S. Barness, LG Prank Makes People Think It's The End Of The World, "The Huffington Post", 9 March 2013, http://www.huffingtonpost.com/2013/09/03/lg-prank-spain_n_3861926.html (accessed: 22 September 2014).

${ }^{12}$ LG pulls apocalyptic interview prank, "Telegraph", 5 September 2013, http://www.telegraph.co.uk/news/ newstopics/howaboutthat/10290405/LG-pulls-apocalyptic-interview-prank.html (accessed: 22 September 2014).

13 D. McCormack, Welcome to the scariest job interview ever!, "Daily Mail”, 5 September 2013, http://www.dailymail.co.uk/news/article-2411950/Scariest-job-interview-LG-terrifies-applicants-Chile-fakingmassive-meteor-crash-outside-office-window-thats-really-ultra-high-def-TV-screen.html (accessed: 22 September 2014).

${ }^{14}$ D. Raven, Is this the world's scariest job interview? LG give job applicants the fright of their lives, "Mirror", 5 September 2013, http://www.mirror.co.uk/news/weird-news/worlds-scariest-job-interview-lg-2252797, (accessed: 22 September 2014).

15 TNT's Red Button Ad Invites Users To "Push To Add Drama”, "Huffington Post", 4 November 2012, http://www.huffingtonpost.com/2012/04/11/tnt-red-button-ad-commercial-add-drama_n_1418731.html, (accessed: 22 September 2014).

${ }^{16}$ M. Blake, 'Push here for Drama': How a quiet Belgian town was turned into a live action movie, complete with punch-ups, gunfights and kidnap... and a sexy biker in lingerie, "Daily Mail", 12 April 2012, http://www.dailymail.co.uk/news/article-2128653/Push-Drama-How-quiet-Belgian-town-turned-live-actionmovie-complete-punch-ups-gunfights-kidnap--sexy-lingerie-clad-biker.html (accessed: 22 September 2014).

17 A.W. Kosner, “Push To Add Drama” Video: Belgian TNT Advert Shows Virality of Manipulated Gestures, "Forbes", 4 December 2012, http://www.forbes.com/sites/anthonykosner/2012/04/12/push-to-add-dramavideo-belgian-tnt-advert-shows-virality-of-manipulated-gestures/ (accessed: 22 September 2014). 
ed job candidates. Pranks, therefore, have to be used with caution in advertising, as they may convert mirth into contempt towards a trickster i.e. a brand.

As practical jokes are a form of disparagement humor, the use of negative emotions should not be a great surprise. From statistical perspective, fearful and derisive branding pranks may be even regarded as more effective in terms of media reach than positive and blissful ones. The most frequently viewed stunts were designed to mock or ridicule the victims. For example, in Pepsi Max "Test drive" video, an unsuspecting car salesman is taken to test drive a car with a disguised NASCAR racer, Jeff Gordon, who dangerously speeds along the streets. Despite the evident emotional harm imposed on a salesman, the video managed to get over $42,947,547$ views in one year ${ }^{18}$. This, however, raises some doubts about delayed effectiveness of pranks: to what extent such number of views and extensive media coverage may compensate for generating unfavorable brand attitudes as a result of a negatively-oriented humor?

For brands which position themselves as fun, witty or entertaining, pranks often become the foundation of long-term brand communications online. Heineken, for example, has been long involved in staging practical jokes which engage and integrate football spectators all over the world. In one of the most exciting stunts, over 1,000 AC Milan fans were maneuvered into a fake classical music concert organized at the same time as a Real Madrid vs. AC Milan soccer game. Another example of using situational humor by Heineken is presented in "The negotiation" video. It depicts men trying desperately to persuade their female partners to spend almost 2,000 USD on two plastic, red, stadium chairs, in order to win a ticket for the UEFA Champions League finals in London (under one condition: they cannot mention the tickets in their negotiations). The abundant portfolio of Heineken pranks comprises also videos with: a fake job interview ("Candidate"), a female stranger in a bar offering a tour to a football game in another country ("The decision"), a challenge to find another half of the ticket in a supermarket (" 3 minutes to the final") and many others. They are all consistently embedded in the communications strategy in order to raise humor and persuasively portray a brand in real-life situations and contexts.

Non-humorous brands (i.e. with no associations to humor) exploit pranks in single campaigns or marketing online events so as to visualize the main product benefit and authenticate it. This is the objective of Nivea "The stress test" prank or Herbal Essence and its "Experiencia" stunt. Another example is "So real it's scary" campaign, in which LG Electronics promote the IPS monitor as providing such realistic vision that may totally captivate the viewers or even evoke extreme reactions of panic, fear, anxiety or thrill. LG pranks are supposed to provide credibility and a sense of authenticity to the brand, as they present genuine expressions of unsuspecting victims caught up in diverse, optically delusive, traps e.g.: in an elevator (a grid of monitors is fixed in an elevator so that it broadcasts an optic illusion of a floor falling down - "Elevator"), in a restroom (monitors, which are installed above a row of urinals in a public restroom, display beautiful women starring and commenting on all visitors - "Stage fright") and at a job interview ("Meteor"). LG positioning statement is not based on humor, but a joke serves temporarily as a vehicle for communicating key functional benefit of a product i.e. visual superiority.

${ }^{18}$ Jeff Gordon: Test Drive | Pepsi Max | Prank, http://www.youtube.com/watch?v=Q5mHPo2yDG8 (accessed: 22 September 2014). 


\section{PRANK EFFECTS ON BRANDS - IMPLICATIONS FROM THEORY OF HU- MOR}

From marketing perspective, it is important to gain insights about the communication effects of pranks. Disappointingly, little academic work has been devoted to consumer studies on practical jokes and their efficacy in digital advertising. However, as pranks belong to a category of humor, one can infer from extant humor literature their possible persuasive powers and their likely impact on consumer behavior.

According to Speck $^{19}$, there are mainly three broad groups of theories of humor response: cognitive-perceptual (e.g. incongruity theories), superiority (e.g. disparagement and affective-evaluative theories) and relief (e.g. psychodynamic theories). From marketing communications perspective, these theories offer a series of approaches which might prove useful in explaining, how humor (esp. used in a form of online pranks) works in terms of branding effects. One of the commonly accepted theoretical concepts is derived from a classical conditioning theory, Heider's balance theory ${ }^{20}$ and a model of attitude formation ${ }^{21}$. The idea is that affective responses, stimulated by humor used in an ad, directly influence (are transferred to) brand attitude without swaying brand recall or recognition ${ }^{22}$. Simply, humorous ads (unlike serious ones) generate excessively higher levels of positive attitudes. This triggers the transfer of affect onto the brand, as individuals strive to keep consistency (balance) in their attitudes and behaviors.

Another conceptualization recognizes humor as a distractive factor which impedes comprehension of the advertising stimuli and its recall. Zillmann et al. ${ }^{23}$ and Woltman Elpers et al. ${ }^{24}$ have argued that respondents are so concentrated on humor, that they show low attentiveness to other layers of the message. Cognitively speaking, humor elicits strong emotions of mirth, pleasure and amusement, which serve as a sufficient encouragement to focus attention ${ }^{25}$. The more intense the humor in the stimuli, the more probable it is to distract the audience from other (non-humor) aspects of this stimuli e.g. a brand. This assumption is frequently used to explain, why funny ads and commercials arrive at simultaneously low brand recall and high ad recall indicators.

19 P.S. Speck, On humor and humor in advertising, Texas Tech University 1987 (Ph.D. Dissertation), https://repositories.tdl.org/ttu-ir/bitstream/handle/2346/19016/31295000275114.pdf?sequence=1 (accessed: 8 August 2014).

${ }^{20}$ F. Heider, The Psychology of Interpersonal Relations, Hillsdale, New Jersey 1958.

${ }^{21}$ S.B. MacKenzie, R.J. Lutz, G.E. Belch, The role of attitude toward the ad as a mediator of advertising effectiveness: a test of competing explanations, "Journal of Marketing Research" 23/2 (1986), p. 130-143; S.B. MacKenzie, R.J. Lutz, An empirical examination of the structural antecedents of attitude toward the ad in an advertising pretesting context, "Journal of Marketing" 1989/53, p. 48-56.

${ }^{22}$ S.B. MacKenzie, R.J. Lutz, G.E. Belch, op. cit., p. 130-143; Prilluk R., B.D. Till, The role of contingency awareness, involvement, and need for cognition in attitude formation, "Journal of the Academy of Marketing Science" 32/3 (2004), p. 329-344.

${ }^{23}$ D. Zillmann, B.R. Williams, J. Bryant, K.R. Boynton, M.A. Wolf, Acquisition of information from educational television as a function of differently paced humorous inserts, "Journal of Educational Psychology" 72/2 (1980), p. 170-180.

${ }^{24}$ J.C.M. Woltman Elpers, A. Mukherjee, W.D. Hoyer, Humor in television advertising: A moment-to-moment analysis, "Journal of Consumer Research" 2004/31, p. 592-598.

${ }^{25}$ R.A. Martin, The Psychology of Humor: An Integrative Approach, Elsevier, Amsterdam 2007. 
As humor is expected to persuade consumers, the Elaboration Likelihood Model (ELM) developed by Petty and Cacioppo ${ }^{26}$, is often adopted to describe how humor can produce various communication effects. Out of two paths to persuasion, peripheral one requires little elaboration, low involvement, and it uses cues and inferences to elicit affective change. Along with this theory, humor can serve as a peripheral cue to persuasion and stimulate delayed responses to brands (including attitudes). However, as noted by Petty and Cacioppo ${ }^{27}$ and Petty et al. $^{28}$, these responses are less persistent over time and less predictive of behavior than attitudes triggered by the central route.

In his work, Speck ${ }^{29}$ suggests that under certain circumstances (e.g. in case of humorous products), humor can serve as a central message argument or it can help boost arousal and focus attention, thus perpetuating central route to persuasion (arousal may motivate individuals to concentrate on the message, while attention would increase their ability to process the message). Nevertheless, in most cases humor serves as an indirect incentive to produce attention and message acceptance. This view is strongly supported by available empirical evidence: while comparing humor to serious advertising messages, many scholars found humor to be more effective in gaining consumers' attention and liking towards the ad and the advertiser ${ }^{30}$. Although much of these studies had been conducted prior to the advent of Internet, the impact of humor on attention is expected to be stable over diverse media channels ${ }^{31}$.

Many theoretical perspectives on humor in advertising (including those described above) do not compete, but complement one another. Unfortunately, the literature provides mixed empirical results on the effects of humor on several outcome variables i.e. comprehension, consumer memory, and brand attitudes ${ }^{32}$. For example Eisend ${ }^{33}$, in his meta-analysis revealed that humor has no significant impact neither on brand recall, nor on comprehension of the stimulus, attitude towards the advertiser and purchase behavior. Weinberger and Campbell ${ }^{34}$, Zhang and Zinkhan ${ }^{35}$ found that humor might aid compre-

${ }^{26}$ R.E. Petty, J.T. Cacioppo, The Elaboration Likelihood Model of persuasion, “Advances in Experimental Social Psychology" 1986/19, p. 123-194.

${ }^{27}$ Ibidem.

${ }^{28}$ R.E. Petty, J. Kasmer, C. Haugtvedt, J.T. Cacioppo, Source and message factors in persuasion: A reply to Stiffs critique of the Elaboration Likelihood Model, "Communication Monographs" 1987/54, p. $233-249$.

29 P.S. Speck, On humor and humor in advertising, Texas Tech University 1987 (Ph.D. Dissertation), https://repositories.tdl.org/ttu-ir/bitstream/handle/2346/19016/31295000275114.pdf?sequence $=1$ (accessed: 8 August 2014).

${ }^{30}$ C.P. Duncan, J.E. Nelson, Effects of Humor in a Radio Advertising Experiment, "Journal of Advertising" 14/2 (1985), p. 33-64; T.J. Madden, M.G. Weinberger, The effects of humor on attention in magazine advertising, "Journal of Advertising” 11/2 (1982), p. 8-14; D.M. Steward, D.H. Furse, Effective television advertising, D.C. Heath and Company, Chicago 1986; M.G. Weinberger, L. Campbell, The use and impact of humor in radio advertising, "Journal of Advertising Research" 31/12-01 (1991), p. 44-52.

${ }^{31}$ M. Eisend, A meta-analysis of humor in advertising, "Journal of the Academy of Marketing Science" 2009/37, p. 191-203.

${ }^{32}$ C.S. Gulas, M.G. Weinberger, op. cit., p. 1-256.

${ }^{33}$ M. Eisend, op. cit., p. 191-203.

${ }^{34}$ M.G. Weinberger, L. Campbell, op. cit., p. 44-52.

35 Y. Zhang, G.M. Zinkhan, Humor in Television Advertising, “Advances in Consumer Research" 1991/18, p. 813-818. 
hension of an ad, while the opposite findings were reported by Gelb and Zinkhan ${ }^{36}$ and Lammers et al. ${ }^{37}$.

Indeed, the inconclusive nature of empirical results suggests that there exist additional factors that might moderate the humor-brand relationship. Out of many moderators, the most important ones are: product category and use, humor type and intensity, perception of humor ${ }^{38}$. In order to gain positive results from humor on brand attitudes, the ads must be firstly perceived as humorous (perception of humor) ${ }^{39}$. Ads perceived as humorous are more effective for low-risk and low-involvement products (product category), as they do not require deep elaboration and weighting alternatives. Under such conditions humor becomes a peripheral cue which indirectly impacts positive responses of consumers ${ }^{40}$.

Based on the above discussion, one may conclude that embedding a prank in an online video, may draw viewers' attention, lead to improved recall of this video, and contribute to positive attitudes towards it. This relationship, however, may differ depending on the promoted product (e.g. low vs. high risk; low vs. high involvement), humor perception, type (e.g. disparagement vs. incongruity) and intensity (e.g. mild vs. intense). Nonetheless, no significant impact on purchase behavior should be expected. These suppositions, however, require further examination. As pranks constitute a very specific category of humor, they need thorough testing in order to establish their exact (and not inferred) influence on brand-related consumer behaviors and reactions.

\section{RISKS AND LIMITATIONS OF PRANKVERTISING}

In theory, a branding prank mostly involves unsuspecting victims maneuvered into eccentric scenarios in public places. A real-life setting and high dependence on spontaneity of non-actors entails a number of potential risks. Firstly, the marketers cannot predict exactly whether and how the audience will understand and react to the joke. As each member of the public assesses a prank based on their own personal experiences, individual sense of humor and subjective knowledge of aesthetics, many performances may sometimes generate unexpected results in terms of consumer understanding, liking, preferences and attitudes towards the trickster (i.e. the brand). For example, Toys"R'Us employed prankvertising in its campaign circled around a theme of "a wish". Brand executives organized a trip for kids; official destination was the forest, but in reality a school bus took children to the huge Toys"R"Us store, where they could have taken any toy of their choice. Despite the unbridled enthusiasm of the "victims", the video was not well received among the Internet users. What was intended to become a blissful and emotional prank, actually gathered a massive number of negative comments e.g.: "shame on you Toys $\mathrm{R}$

\footnotetext{
${ }^{36}$ B.D. Gelb, G.M. Zinkhan, Humor and advertising effectiveness after repeated exposures to a radio commercial, "Journal of Advertising" 15/2 (1986), p. 15-34.

${ }^{37}$ H.B. Lammers, L. Liebowitz, G.E. Seymour, J.E. Hennessey, Humor and cognitive response to advertising stimuli: A trace consolidation approach, "Journal of Business Research" 11/2 (1983), p. 173-185.

${ }^{38}$ P. De Pelsmacker, M. Geuens, The advertising effectiveness of different levels of intensity of humour and warmth and the moderating role of top of mind awareness and degree of product use, "Journal of Marketing Communications" 5/3 (1999), p. 113-129; M.G. Weinberger, C.S. Gulas, The Impact of Humor in Advertising: A Review, "Journal of Advertising" 21/4 (1992), p. 35-59.

${ }^{39}$ K. Flaherty, M.G. Weinberger, C.S. Gulas, The Impact of Perceived Humor, Product Type, and Humor Style in Radio Advertising, "Journal of Current Issues and Research in Advertising" 26/1 (2004), p. 25-36.

${ }^{40}$ M.G. Weinberger, L. Campbell, B. Brody, Effective Radio Advertising, Lexington Books, New York 1994.
} 
Us! take those kids to the forest!!”; „This promotion makes me sad. Portraying an outdoor field trip as the boring alternative to a trip to $\operatorname{TrU}$ is a cheap shot. Very unfortunate choice" ${ }^{\prime 1}$. Notwithstanding the impressive number of 1,120,685 views, the video collected 2,760 dislikes (along with only 1,071 likes) ${ }^{42}$ and the brand was criticized for using children for marketing purposes.

Secondly, the reactions of the prankees can be unpredictable to the pranksters. Certain scenarios may be insufficiently appealing or unengaging for participants, as in case of Kupiec (a brand of grain, rice and breakfast products) which did not succeed in attracting masses of people in their practical joke presented in the "Push and something will happen" video. Marketers do not have enough data, resources and equipment to anticipate and fully control the behavior of prank objects and they often need to rely on their individual feelings and subjective presumptions. This leads sometimes to the situations in which pranks become too provocative in terms of personal privacy or social acceptance, and they, therefore, inflict emotional distress, pain or even cause litigations and more advanced legal actions. A French producer of household goods, Cuisinella, conducted a prank that involved (allegedly real) pedestrians who became the objects of a street shooting. Although the targets were actually shot with fake bullets, they were forced into the coffins and finally transported to the mortuary. Staged or not, this stunt was regarded as outrageously invasive, abusive and very harmful to the victims. If marketers expose their prank objects to certain liability, fear or danger, the consequences may become surprisingly extreme. Toyota, for instance, is sued for stalking and terrorizing a consumer (a result of an unfortunate prank promoting the new model of a car), who is now demanding $10,000,000$ USD in damages for psychological injury ${ }^{43}$. In such situations, a better solution is to stage an ideally veracious prank (with professional actors) in order to avoid potential problems and accusations.

\section{CONCLUSIONS}

A branding prank is an advertising act disguised as a practical joke. It is designed by marketers to make people laugh and learn about the brand. As humor can appeal to sizeable audiences, pranks are believed to become a convenient solution for mass communication of brands and products. They are regarded as very compelling performances for large number of consumers, due to the use of fun, real-life settings, and non-actors. Contrary to traditional advertising, prankvertising is expected to provide greater credibility to the brand and offer viewers authentic experiences along with real entertainment value. Despite their unquestionable attractiveness, branding pranks involve, however, certain managerial limitations and challenges.

Firstly, the Internet has extended the environment for staging, recording and diffusion of branding pranks, but it does not provide satisfactory tools for anticipating and measuring their results. It allows pranks to proliferate, become interactive and address versatile audiences. Social media facilitate the dissemination of branding videos; it is the

${ }^{41}$ Busloads of kids get surprise trip to Toys "R" Us, https://www.youtube.com/watch?v=q5SXybm6bss (accessed: 20 September 2014).

${ }^{42}$ Ibidem.

${ }^{43}$ D. Gianatasio, Prankvertising: Are Outrageous Marketing Stunts Worth the Risks?, "Adweek", 1 April 2013, http://www.adweek.com/news/advertising-branding/prankvertising-are-outrageous-marketing-stunts-worthrisks-148238? page=1 (accessed: 1 September 2014). 
viewers, however, not brand owners, who are empowered to comment, share, evaluate and forward the footage online. Such balance of power gives less importance to a brand itself and makes pranks less predictable as for their marketing outcomes. If a prank generates outrage or misunderstanding, negative associations will be attributed to the brand across many Internet channels. In general, the reception of pranks by online communities is largely unknown, and it is not only typical for controversial stunts (comp. Cuisinella), but also for less provocative ones (as was in case of Toys"R"Us).

Secondly, humor is not a fully effective tactic for message content in marketing communication of brands. Humor has been long used in traditional advertising in order to attract attention, encourage involvement with the message and the medium. Unfortunately, humor often serves as a distraction from the advertising content and it does not improve memory traces about an advertiser (esp. in case of high-involvement product categories). In other words, it is the humorous stimuli that consumers mostly remember, not the brand itself. Additionally, joke cognition is a highly subjective process i.e. not every audience member has skills, competences and identical sense of humor to decode a joke and understand its meaning. While pranks are a form of disparagement humor, they often become performances of mockery, which allow spectators to laugh at someone else's expense. Not everybody enjoys ridiculing other people; not everybody laughs at the same things, ideas and situations.

Thirdly, the underlying limitation to all prankvertising efforts is the void in data on the effectiveness of pranks and their possible impact on immediate and delayed consumer behaviors. Practical jokes as branding weapons are very difficult to capture, measure and evaluate, due to: (1) dynamic nature of such performances, (2) many potentially moderating and mediating factors, (3) the attribution effect (i.e. the problem of attributing and tracing the link between specific results and investments). As a result, there are several questions to be addressed in future theoretical and empirical studies e.g.:

- What specific communication goals can be achieved through the use of pranks and to what extent?

- What factors (psychological, sociological, cultural, environmental etc.) moderate the outcomes?

- What immediate and delayed responses can be expected?

- What processes cause humor to occur in branding pranks?

- Which type of prank (staged vs. real; based on negative vs. positive emotions etc.) is more effective in driving desired consumer responses?

- How much of disparagement humor impacts the positive vs. negative effects of a branding prank?

- How and to what extent the effectiveness of a branding prank depends on a product category?

Future research efforts should focus on examining these questions and assessing prank influences with regard to diverse ROI and brand indicators.

\section{REFERENCES}

[1] A dramatic surprise on a quiet square, http://www.youtube.com/watch?v=316AzLYfAzw (accessed: 22 September 2014). 
[2] Barness S., LG Prank Makes People Think It's The End Of The World, "The Huffington Post", 9 March 2013, http://www.huffingtonpost.com/2013/09/03/lg-prank-spain_n_3861926.html (accessed: 22 September 2014).

[3] Bauman R., Story, Performance, and Event: Contextual Studies in Oral Narrative, Cambridge UP, Cambridge 1986, p. 144.

[4] Blake M., 'Push here for Drama': How a quiet Belgian town was turned into a live action movie, complete with punch-ups, gunfights and kidnap... and a sexy biker in lingerie, "Daily Mail”, 12 April 2012, http://www.dailymail.co.uk/news/article-2128653/Push-Drama-Howquiet-Belgian-town-turned-live-action-movie-complete-punch-ups-gunfights-kidnap--sexylingerie-clad-biker.html (accessed: 22 September 2014).

[5] Busloads of kids get surprise trip to Toys " $R$ " Us, https://www.youtube.com/watch? $\mathrm{v}=$ q5SXybm6bss (accessed: 20 September 2014).

[6] De Pelsmacker P., Geuens M., The advertising effectiveness of different levels of intensity of humour and warmth and the moderating role of top of mind awareness and degree of product use, "Journal of Marketing Communications" 5/3 (1999), p. 113-129.

[7] Duncan C.P., Nelson J.E., Effects of Humor in a Radio Advertising Experiment, "Journal of Advertising" 14/2 (1985), p. 33-64.

[8] Eisend M., A meta-analysis of humor in advertising, "Journal of the Academy of Marketing Science" 2009/37, p. 191-203.

[9] Flaherty K., Weinberger M.G., Gulas C.S., The Impact of Perceived Humor, Product Type, and Humor Style in Radio Advertising, "Journal of Current Issues and Research in Advertising" 26/1 (2004), p. 25-36.

[10] Gelb B.D., Zinkhan G.M., Humor and advertising effectiveness after repeated exposures to a radio commercial, "Journal of Advertising" 15/2 (1986), p. 15-34.

[11] Gianatasio D., Prankvertising: Are Outrageous Marketing Stunts Worth the Risks? "Adweek", 1 April 2013, http://www.adweek.com/news/advertising-branding/prankvertising-areoutrageous-marketing-stunts-worth-risks-148238?page $=1$ (accessed: 1 September 2014).

[12] Gulas C.S., Weinberger M.G., Humor in Advertising: A Comprehensive Analysis, M.E. Sharpe, New York 2006.

[13] Heider F., The Psychology of Interpersonal Relations, Hillsdale, New Jersey 1958.

[14] Hsieh J.-K., Hsieh Y.-C., Tang Y.-C., Exploring the disseminating behaviors of eWOM marketing: persuasion in online video, "Electronic Commerce Research" 2012/12, s. 201-224.

[15] Jeff Gordon: Test Drive | Pepsi Max | Prank, http://www.youtube.com/watch?v= Q5mHPo2yDG8 (accessed: 22 September 2014).

[16] Karpińska-Krakowiak M., Consumers, Play and Communitas - an Anthropological View on Building Consumer Involvement on a Mass Scale, "Polish Sociological Review" 3/187 (2014), p. 317-331.

[17] Kosner A.W., "Push To Add Drama” Video: Belgian TNT Advert Shows Virality of Manipulated Gestures, "Forbes", 4 December 2012, http://www.forbes.com/sites/anthonykosner/ 2012/04/12/push-to-add-drama-video-belgian-tnt-advert-shows-virality-of-manipulatedgestures/ (accessed: 22 September 2014).

[18] Lammers H.B., Liebowitz L., Seymour G.E., Hennessey J.E., Humor and cognitive response to advertising stimuli: A trace consolidation approach, "Journal of Business Research" 11/2 (1983), p. 173-185.

[19] LG pulls apocalyptic interview prank, "Telegraph", 5 September 2013, http://www.telegraph.co.uk/news/newstopics/howaboutthat/10290405/LG-pulls-apocalypticinterview-prank.html (accessed: 22 September 2014).

[20] MacKenzie S.B, Lutz R.J., Belch G.E., The role of attitude toward the ad as a mediator of advertising effectiveness: a test of competing explanations, "Journal of Marketing Research" 23/2 (1986), p. 130-143.

[21] MacKenzie S.B., Lutz R.J., An empirical examination of the structural antecedents of attitude toward the ad in an advertising pretesting context, "Journal of Marketing" 1989/53, p. 48-56. 
[22] Madden T.J., Weinberger M.G., The effects of humor on attention in magazine advertising, "Journal of Advertising" 11/2 (1982), p. 8-14.

[23] Martin R.A., The Psychology of Humor: An Integrative Approach, Elsevier, Amsterdam 2007.

[24] McCormack D., Welcome to the scariest job interview ever!, "Daily Mail", 5 September 2013, http://www.dailymail.co.uk/news/article-2411950/Scariest-job-interview-LG-terrifiesapplicants-Chile-faking-massive-meteor-crash-outside-office-window-thats-really-ultra-highdef-TV-screen.html (accessed: 22 September 2014).

[25] Media firms are making big bets on online video, still an untested medium, New York, 3 May 2014, http://www.economist.com/news/business/21601558-media-firms-are-making-big-betsonline-video-still-untested-medium-newtube.

[26] Petty R.E., Cacioppo J.T., The Elaboration Likelihood Model of persuasion, "Advances in Experimental Social Psychology" 1986/19, p. 123-194.

[27] Petty R.E., Kasmer J., Haugtvedt C., Cacioppo J.T., Source and message factors in persuasion: A reply to Stiffs critique of the Elaboration Likelihood Model, "Communication Monographs" 1987/54, p. 233-249.

[28] Prilluk R., Till B.D., The role of contingency awareness, involvement, and need for cognition in attitude formation, "Journal of the Academy of Marketing Science" 32/3 (2004), p. 329344.

[29] Raven D., Is this the world's scariest job interview? LG give job applicants the fright of their lives, "Mirror", 5 September 2013, http:/www.mirror.co.uk/news/weird-news/worlds-scariestjob-interview-lg-2252797 (accessed: 22 September 2014).

[30] So Real it's Scary, http://www.youtube.com/watch?v=NeXMxuNNIE8 (accessed: 22 September 2014).

[31] Speck P.S., On humor and humor in advertising, Texas Tech University 1987 (Ph.D. Dissertation), https://repositories.tdl.org/ttu-ir/bitstream/handle/2346/19016/31295000275114.pdf? sequence $=1$ (accessed: 8 August 2014).

[32] Steward D.M., Furse D.H., Effective television advertising, D.C. Heath and Company, Chicago 1986.

[33] TNT's Red Button Ad Invites Users To "Push To Add Drama", "Huffington Post", 4 November 2012, http://www.huffingtonpost.com/2012/04/11/tnt-red-button-ad-commercial-adddrama_n_1418731.html (accessed: 22 September 2014).

[34] Weinberger M.G., Gulas C.S., The Impact of Humor in Advertising: A Review, "Journal of Advertising" 21/4 (1992), p. 35-59.

[35] Weinberger M.G., Campbell L., Brody B., Effective Radio Advertising, Lexington Books, New York 1994.

[36] Weinberger M.G., Campbell L., The use and impact of humor in radio advertising, "Journal of Advertising Research" 31/12-01 (1991), p. 44-52.

[37] WestJet Christmas Miracle: real-time giving, http://www.youtube.com/watch?v=zIEIvi2MuEk (accessed: 22 September 2014).

[38] Woltman Elpers J.C.M., Mukherjee A., Hoyer W.D., Humor in television advertising: A moment-to-moment analysis, "Journal of Consumer Research" 2004/31, p. 592-598.

[39] Zhang Y., Zinkhan G.M., Humor in Television Advertising, "Advances in Consumer Research" 1991/18, p. 813-818.

[40] Zillmann D., Williams B.R., Bryant J., Boynton K.R., Wolf M.A., Acquisition of information from educational television as a function of differently paced humorous inserts, "Journal of Educational Psychology" 72/2 (1980), p. 170-180. 


\section{APPENDIX}

Table 1. List of branding pranks cited in the text

\begin{tabular}{|c|c|c|c|}
\hline $\begin{array}{l}\text { BRAND - A } \\
\text { PRANKSTER }\end{array}$ & $\begin{array}{l}\text { TITLE OF A } \\
\text { PRANK }\end{array}$ & $\begin{array}{l}\text { EMOTIONS PLAYED } \\
\text { BY A PRANKSTER }\end{array}$ & URL ADDRESS \\
\hline Carlsberg & Bikers in cinema & $\begin{array}{l}\text { Hilarity, surprise, excite- } \\
\text { ment, fear, confusion }\end{array}$ & $\begin{array}{l}\text { https://www.youtube.com/ } \\
\text { watch?v=RS3iB47nQ6E }\end{array}$ \\
\hline Carlsberg & $\begin{array}{l}\text { Carlsberg puts } \\
\text { friends to the test }\end{array}$ & $\begin{array}{l}\text { Hilarity, surprise, excite- } \\
\text { ment, fear, confusion }\end{array}$ & $\begin{array}{l}\text { https://www.youtube.com/ } \\
\text { watch?v=vs1wMp84_BA }\end{array}$ \\
\hline Coca-Cola & $\begin{array}{l}\text { Singapore recycle } \\
\text { happiness ma- } \\
\text { chine }\end{array}$ & $\begin{array}{l}\text { Happiness, warmth, hilarity, } \\
\text { surprise }\end{array}$ & $\begin{array}{l}\text { https://www.youtube.com/ } \\
\text { watch?v=4D-RejzbC0Q }\end{array}$ \\
\hline Coca-Cola & Happiness truck & $\begin{array}{l}\text { Happiness, warmth, hilarity, } \\
\text { surprise }\end{array}$ & $\begin{array}{l}\text { https://www.youtube.com/ } \\
\text { watch?v=hVap-ZxSDeE }\end{array}$ \\
\hline Coca-Cola & $\begin{array}{l}\text { Happiness ma- } \\
\text { chine (London) }\end{array}$ & $\begin{array}{l}\text { Happiness, warmth, hilarity, } \\
\text { surprise }\end{array}$ & $\begin{array}{l}\text { https://www.youtube.com/ } \\
\text { watch?v=M0D3jKLz6sA }\end{array}$ \\
\hline Cuisinella & Sniper shot & $\begin{array}{l}\text { Fear, anger, shock, pain, } \\
\text { surprise }\end{array}$ & $\begin{array}{l}\text { https://www.youtube.com/ } \\
\text { watch?v=zdsdnMKTVAc }\end{array}$ \\
\hline$\overline{\mathrm{DHL}}$ & Trojan mailing & Hilarity, surprise, awe & $\begin{array}{l}\text { https://www.youtube.com/ } \\
\text { watch?v=07y1Ib6Di7k }\end{array}$ \\
\hline Heineken & $\begin{array}{l}\text { Champions } \\
\text { league match vs. } \\
\text { classical concert }\end{array}$ & $\begin{array}{l}\text { Hilarity, surprise, happi- } \\
\text { ness, excitement, awe }\end{array}$ & $\begin{array}{l}\text { https://www.youtube.com/ } \\
\text { watch?v=wB7DIo3nJas }\end{array}$ \\
\hline Heineken & Candidate & $\begin{array}{l}\text { Hilarity, surprise, happi- } \\
\text { ness, warmth }\end{array}$ & $\begin{array}{l}\text { https://www.youtube.com/ } \\
\text { watch?v=Aq6y3RO12UQ }\end{array}$ \\
\hline Heineken & The decision & $\begin{array}{l}\text { Hilarity, surprise, happi- } \\
\text { ness, excitement }\end{array}$ & $\begin{array}{l}\text { https://www.youtube.com/ } \\
\text { watch?v=L0cNKHke7EY }\end{array}$ \\
\hline Heineken & $\begin{array}{l}3 \text { minutes to the } \\
\text { final }\end{array}$ & $\begin{array}{l}\text { Hilarity, surprise, happi- } \\
\text { ness, excitement }\end{array}$ & $\begin{array}{l}\text { https://www.youtube.com/ } \\
\text { watch?v=JbYXJd3pRdY }\end{array}$ \\
\hline Heineken & The negotiation & $\begin{array}{l}\text { Hilarity, surprise, happi- } \\
\text { ness, warmth }\end{array}$ & $\begin{array}{l}\text { https://www.youtube.com/ } \\
\text { watch?v=WHjjy } 2 \mathrm{kfBq} 4\end{array}$ \\
\hline $\begin{array}{l}\text { Herbal Essenc- } \\
\text { es }\end{array}$ & Experiencia & $\begin{array}{l}\text { Arousal, surprise, amuse- } \\
\text { ment }\end{array}$ & $\begin{array}{l}\text { https://www.youtube.com/ } \\
\text { watch?v=dIhXOCHIcDM }\end{array}$ \\
\hline Kupiec & $\begin{array}{l}\text { Push and some- } \\
\text { thing will happen }\end{array}$ & $\begin{array}{l}\text { Excitement, awe, surprise, } \\
\text { amusement }\end{array}$ & $\begin{array}{l}\text { http://www.youtube.com/w } \\
\text { atch?v=ITwHCamudWs }\end{array}$ \\
\hline LG & Meteor & $\begin{array}{l}\text { Hilarity, surprise, excite- } \\
\text { ment, fear, embarrassment, } \\
\text { confusion }\end{array}$ & $\begin{array}{l}\text { https://www.youtube.com/ } \\
\text { watch?v=4xQb9K1-O3E }\end{array}$ \\
\hline LG & Elevator & $\begin{array}{l}\text { Hilarity, surprise, excite- } \\
\text { ment, fear }\end{array}$ & $\begin{array}{l}\text { https://www.youtube.com/ } \\
\text { watch?v=NeXMxuNNlE8 }\end{array}$ \\
\hline $\mathrm{LG}$ & Stage fright & $\begin{array}{l}\text { Hilarity, surprise, excite- } \\
\text { ment, embarrassment, } \\
\text { confusion }\end{array}$ & $\begin{array}{l}\text { https://www.youtube.com/ } \\
\text { watch?v=jOpccxCJPsY }\end{array}$ \\
\hline McDonald's & $\begin{array}{l}\text { Big Mac mind } \\
\text { tests }\end{array}$ & Hilarity, surprise & $\begin{array}{l}\text { https://www.youtube.com/ } \\
\text { watch?v=PTJaztFBKL8 }\end{array}$ \\
\hline Nivea & The stress test & $\begin{array}{l}\text { Hilarity, surprise, fear, } \\
\text { embarrassment, confusion }\end{array}$ & $\begin{array}{l}\text { https://www.youtube.com/ } \\
\text { watch?v=n3hVfP8lMfc }\end{array}$ \\
\hline Pepsi Max & Test drive & $\begin{array}{l}\text { Hilarity, derision, fear, } \\
\text { surprise }\end{array}$ & $\begin{array}{l}\text { https://www.youtube.com/ } \\
\text { watch?v=Q5mHPo2yDG8 }\end{array}$ \\
\hline Samsung & All eyes on $S 4$ & Happiness, hilarity, sur- & https://www.youtube.com/ \\
\hline
\end{tabular}




\begin{tabular}{|l|l|l|l|}
\hline & & $\begin{array}{l}\text { prise, excitement, amuse- } \\
\text { ment }\end{array}$ & watch?v=CsGlzu2NzX0 \\
\hline $\begin{array}{l}\text { The Weather } \\
\text { Channel }\end{array}$ & Bus shelter & Hilarity, surprise & $\begin{array}{l}\text { http://www.youtube.com/w } \\
\text { atch?feature=player_embed } \\
\text { ded\&v=6M-JQktwrXU }\end{array}$ \\
\hline TNT & $\begin{array}{l}\text { Push to add dra- } \\
\text { ma }\end{array}$ & $\begin{array}{l}\text { Hilarity, surprise, happi- } \\
\text { ness, excitement }\end{array}$ & $\begin{array}{l}\text { https://www.youtube.com/ } \\
\text { watch?v=316AzLYfAzw }\end{array}$ \\
\hline TNT & $\begin{array}{l}\text { Push to add dra- } \\
\text { ma on an ice-cold } \\
\text { day }\end{array}$ & $\begin{array}{l}\text { Hilarity, surprise, happi- } \\
\text { ness, excitement }\end{array}$ & $\begin{array}{l}\text { https://www.youtube.com/ } \\
\text { watch?v=ZIkPeZKP-d4 }\end{array}$ \\
\hline Toys"R"Us & $\begin{array}{l}\text { Busloads } \text { of kids } \\
\text { get surprise trip } \\
\text { to Toys"R } \text { "Us }\end{array}$ & $\begin{array}{l}\text { Excitement, awe, surprise, } \\
\text { amusement }\end{array}$ & $\begin{array}{l}\text { https://www.youtube.com/ } \\
\text { watch?v=q5SXybm6bss }\end{array}$ \\
\hline Westjet & $\begin{array}{l}\text { Christmas miracle } \\
\text { Happiness, warmth, hilarity, } \\
\text { surprise, nostalgia }\end{array}$ & $\begin{array}{l}\text { https://www.youtube.com/ } \\
\text { watch?v=zIEIvi2MuEk }\end{array}$ \\
\hline
\end{tabular}

\section{PRANKVERTISING - PSIKUS JAKO NOWA FORMA REKLAMY MARKI W INTERNECIE}

Praktyczny żart (tzw. psikus) stanowi formę humoru negatywnego; jest to zabawne i wcześniej zaplanowane działanie, przedsięwzięcie czy zdarzenie, które ma na celu rozśmieszenie publiczności, ale również wyśmianie ofiary (bohatera) żartu. Mimo że zarówno pozytywny, jak i negatywny humor od lat jest dosyć powszechnie wykorzystywaną taktyką w reklamie, praktyczne żarty jawią się jako stosunkowo nowe zjawisko reklamowe. Rozwój Internetu i mediów społecznościowych stworzył szerokie możliwości stosowania psikusów jako ukrytych reklam wbudowanych w strategie komunikacji marketingowej online. Coraz więcej firm wykorzystuje tę formę żartu w swoich działaniach komunikacyjnych i postrzega ją jako innowacyjne rozwiązanie pozwalające na zaangażowanie konsumentów w Internecie. Ze względu na brak badań oraz analiz naukowych poświęconych tej tematyce, niniejszy artykuł formułuje teoretyczne i praktyczne ramy dla psikusów, a także analizuje ich potencjał w zakresie budowania marki (np. w obszarze maksymalizacji zasięgu, ekspozycji marki, tworzenia jej widoczności, przyciągania uwagi konsumentów, obudowywania marki w silne emocjonalnie znaczenia). Do analizy potencjalnego oddziaływania praktycznych żartów wykorzystano koncepcje $\mathrm{z}$ teorii humoru oraz dane wtórne zgromadzone przez autorów. Ostatnia część tekstu została poświęcona charakterystyce kluczowych wyzwań, ryzyka i ograniczeń z tytułu realizacji psikusów na potrzeby reklamowe oraz omówieniu ich na licznych przykładach. Zidentyfikowano również główne obszary badawcze wymagające dodatkowego wysiłku naukowego oraz postawiono pytania, które należy uwzględnić w przyszłych badaniach empirycznych.

Słowa kluczowe: psikus, marka, reklama online, prankvertising, zarządzanie marką, strategie reklamowe, humor

\section{DOI: 10.7862/rz.2014.mmr.31}

Tekst złożono w redakcji: wrzesień 2014

Przyjęto do druku: październik 2014 